\title{
Jacques de Temmerman et Gilbert Stevens, Denis Marion. Essai de bibliographie
}

Jean-Paul De Nola

\section{(2) OpenEdition}

\section{Journals}

Édition électronique

URL : http://journals.openedition.org/studifrancesi/5431

DOI : 10.4000/studifrancesi.5431

ISSN : 2427-5856

Éditeur

Rosenberg \& Sellier

\section{Édition imprimée}

Date de publication : 1 décembre 2016

Pagination : 565

ISSN : 0039-2944

\section{Référence électronique}

Jean-Paul De Nola, « Jacques de Temmerman et Gilbert Stevens, Denis Marion. Essai de bibliographie », Studi Francesi [En ligne], 180 (LX | III) | 2016, mis en ligne le 01 janvier 2017, consulté le 18 septembre 2020. URL : http://journals.openedition.org/studifrancesi/5431 ; DOI : https://doi.org/10.4000/ studifrancesi.5431

Ce document a été généré automatiquement le 18 septembre 2020

\section{(c) (†) $\odot$}

Studi Francesi è distribuita con Licenza Creative Commons Attribuzione - Non commerciale - Non opere derivate 4.0 Internazionale. 


\section{Jacques de Temmerman et Gilbert} Stevens, Denis Marion. Essai de bibliographie

Jean-Paul De Nola 


\section{RÉFÉRENCE}

JACQUES DE TEMMERMAN et GILBERT STEVEnS, Denis Marion. Essai de bibliographie. Mons,

Université de Mons, 2015, 84 pp.

1 Denis Marion (1906-2000), je le connaissais à travers ses chroniques parisiennes, publiées sous son vrai nom-Marcel Defosse - dans le grand quotidien vespéral de Bruxelles. On aurait souhaité que ces articles fussent enregistrés tous, un courrier après l'autre, un "billet dur" après l'autre, dans cet Essai de bibliographie au lieu de figurer sous le titre général «Collaborations au Soir» (1927, 1933-1940, 1945-1976) et "au Soir illustré» $(1946,1948,1950,1952-1959,1966)$.

2 À part cela, la publication que nous avons sous les yeux fait très utilement le tour de l'œuvre abondante et variée de cet écrivain belge peu connu: critique cinématographique (biographe d'Eric von Stroheim, d'André Malraux et d'Ingmar Bergman), aide-cinéaste, polémiste antifasciste, auteur dramatique (Le juge de Malte, L'Affaire Fualdès), romancier (Si peu que rien), traducteur de l'anglais (Poe, Defoe) et du néerlandais...

3 Cette bibliographie comprend la liste des volumes de Marion, les originaux aussi bien que les traductions, puis les œuvres destinées au cinéma, à la radio et à la télévision, sa participation à des ouvrages collectifs et numéros spéciaux, ses collaborations aux périodiques. Le tout est précédé d'un avant-propos par Catherine GRAVET, plein de sensibilité et d'humour, et des pages intéressantes que feu Paul Delsemme avait destinées à «Denis Marion, écrivain engagé». 